UDC $622.83: 622.283$

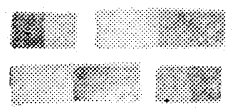

論交報告

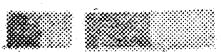

\title{
円形立坑ライニングに作用する地圧によつて ライニング内に生じる応力についで
}

$\begin{array}{llllll}\text { 正会 } & \text { 員 } & \text { 平松 } & \text { 良 } & \text { 雄** } \\ \text { 正会 員 } & \text { 岡 } & & \text { 行 } & \text { 俊 } \\ \text { 正** } \\ \text { 正員 } & \text { 荻 } & \text { 野 } & \text { 正 } & \text { 二**** }\end{array}$

The Stress in a Circular Shaft Lining Caused by Earth Pressure Acting on It.

Yoshio HIRAMATSU, Yukitoshi OKA and Shoji OGINO

In this paper is described the results of analytical study on the stress in a circular shaft lining caused by the earth pressure distributed uniformly or irregularly. By employing the results obtained, the stress distributions on the inner and the outer surfaces of shaft linings subjected to nine states of earth pressure are calculated.

The authors have presented a method to estimate the possible maximum stresses in a shaft lining for the purpose of contributing to the proper design of a shaft lining.

\section{1. 緒}

\section{言}

従来，立坑ライニングに關する研究は二三発表されて いるが1)，まだその設計の基準が確立されていない。こ れはライニングに作用する地圧の状態が十分明らかにさ れていないことと，また仮りに地压の状態が分つても， ライニング内に生じる応力が十分明らかにされていない からである。

筆者らは, 立坑ランニングの力学的研究の一環として, さきに, 円形立坑ライニングに現われる応力の測定結果 を報告したが2，それに引続き，この論文においては， ライニングに作用する地圧によつてライニング内に生じ る応力を解析的に研究した結果を報告し, 立坑ライニン グの設計のための一つの基礎資料を提供したいと思う。

\section{2. 解 析}

\section{$2 \cdot 1$ ライニングの外壁面上の数個所に地圧が集中的 に作用する場合の応力}

第 1 罒に示すように, ライニングの内半径を $a \mathrm{~cm}$, 外半径を $b \mathrm{~cm}$ とし, 外壁面上の $m$ 個矿に, それぞれ異 なる強さの地压 $p_{i} \mathrm{~kg} / \mathrm{cm}^{2}$ が異なる幅 (中心角 $2 \phi_{i} \mathrm{rad}$ ) に分布して作用するものとし，これらの $m$ 個の地圧のお のおのの中心を通る半径が極座標の原線となす角を $\theta_{i}$ $\mathrm{rad}$ とする。ここに $i$ は $1,2,3, \cdots \cdots, m$ である。この 解析においては, ライニングを任意の二つの接近した水

\footnotetext{
* 昭和 35 年 7 月 15 日受理

** 工博 京都大学教授 鉱山学教室

**** 工博 京都大学助乎 铒山学教室

***** 山口大学助教授 鉱山学教室
}

平断面で切つたとき, これらの断面にはさまれた部分に 作用する地圧は釣合を保つているものと仮定する。すな わち,

$$
\left.\begin{array}{c}
\sum_{i=1}^{m} p_{i} \sin \phi_{i} \cos \theta_{i}=0, \\
\sum_{i=1}^{m} p_{i} \sin \phi_{i} \sin \theta_{i}=0 .
\end{array}\right\}
$$

さて，極座標を用いた場合の Airy の応力関数の一般 式はつぎのようである。

$$
\begin{aligned}
\phi & =A_{0} r^{2}+B_{0} \log r+D_{0} r^{2} \log r+K_{0} r^{2} \theta+H_{0} \theta \\
& +A_{1} r^{3} \cos \theta+B_{1} r^{-1} \cos \theta+C_{1} r \theta \sin \theta \\
& +D_{1} r \log r \cos \theta+A_{1}{ }^{3} \sin \theta+B_{1}{ }^{\prime} r^{-1} \sin \theta \\
& -C_{1}{ }^{\prime} r \cos \theta+D_{1}{ }^{\prime} r \log r \sin \theta \\
& +\sum_{n=2}^{\infty}\left\{\left(A_{n} r^{n+2}+B_{n} r^{-n}+C_{n} r^{n}\right.\right.
\end{aligned}
$$

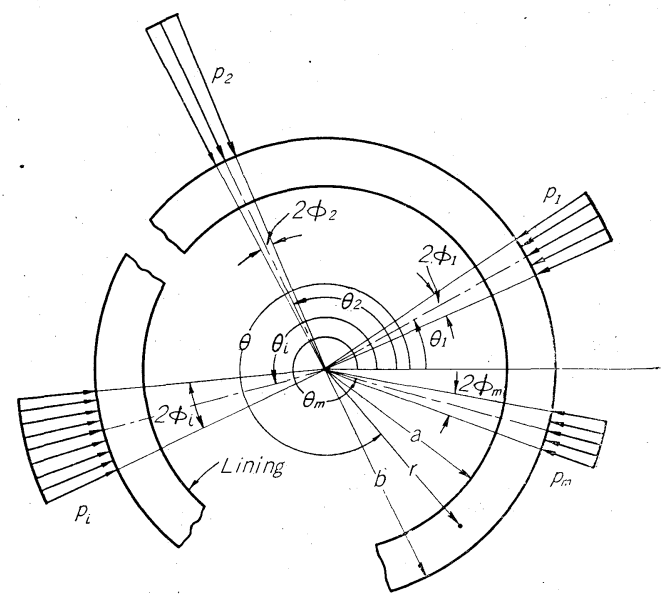

第 1 図 
$\left.+D_{n} r^{-n+2}\right) \cos n \theta+\left(A_{n}^{\prime} r^{n+2}+B_{n}^{\prime} r^{-n}\right.$

$\left.\left.+C_{n} r^{n}+D_{n}^{\prime} r^{-n+2}\right) \sin n \theta\right\}$.

ここに $A_{0}, B_{0}, D_{0}, K_{0}, H_{0}, A_{1}, B_{1}, \cdots \cdots$ は定数である。 ところで，この問題においては変位は 1 価でなければな らないから，(2) 式から変位を示す式を導いたとき，1 価でない項があつてはならない。それゆえ，

$$
D_{0}=K_{0}=0 \text {. }
$$

したがつて, 各応力成分 $\sigma_{r}, \sigma_{\theta}, \tau_{r \theta}$ は次式のようにな る。

$$
\begin{aligned}
& \sigma_{r}=2 A_{0}+B_{0} r^{-2} \\
& +2\left\{A_{1} r-B_{1} r^{-3}+\left(2 C_{1}+D_{1}\right) r^{-1}\right\} \cos \theta \\
& +2\left\{A_{1}{ }^{\prime} r-B_{1}{ }^{\prime} r^{-3}+\left(2 C_{1}{ }^{\prime}+D_{1}{ }^{\prime}\right) r^{-1}\right\} \sin \theta \\
& -\sum_{n=2}^{\infty}\left[\left\{(n-2)(n+1) A_{n} r^{n}+n(n+1) B_{n} r^{-n-2}\right.\right. \\
& \left.+n(n-1) C_{n} r^{n-2}+(n+2)(n-1) D_{n} r^{-n}\right\} \cos n \theta \\
& -\left\{(n-2)(n+1) A_{n}^{\prime} r^{n}+n(n+1) B_{n}^{\prime} r^{-n-2}\right. \\
& \left.+n(n-1) C_{n^{\prime}} r^{n-2}+(n+2)(n-1) D_{n^{\prime}} r^{-n}\right\} \\
& \sin n \theta] \text {, } \\
& \boldsymbol{\sigma}_{\theta}=2 A_{0}-B_{0} r^{-2} \\
& +2\left(3 A_{1} r+B_{1} r^{-3}+D_{1} r^{-1}\right) \cos \theta \\
& +2\left(3 A_{1}^{\prime} r+B_{1}^{\prime} r^{-3}+D_{1}^{\prime} r^{-1}\right) \sin \theta \\
& +\sum_{n=2}^{\infty}\left[\left\{(n+2)(n+1) A_{n} r^{n}+n(n+1) B_{n} r^{-n-2}\right.\right. \\
& \left.+n(n-1) C_{n} r^{n-2}+(n-2)(n-1) D_{n} r^{-n}\right\} \cos n \theta \\
& +\left\{(n+2)(n+1) A_{n}^{\prime} r^{n}+n(n+1) B_{n}^{\prime} r^{-n-2}\right. \\
& \left.+n(n-1) C_{n}^{\prime} r^{n-2}+(n-2)(n-1) D_{n}^{\prime} r-n\right\}
\end{aligned}
$$

(1)

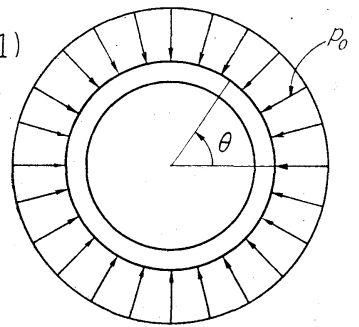

(4)

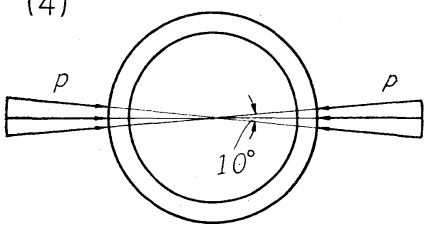

(7)

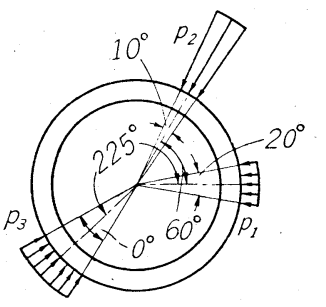

(2)

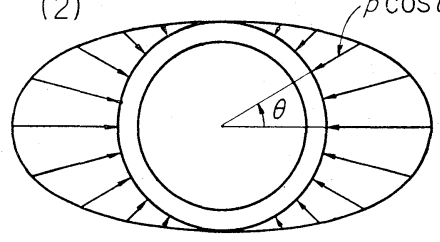

(5)

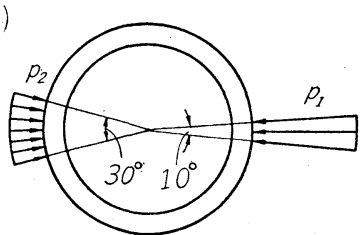

(8)

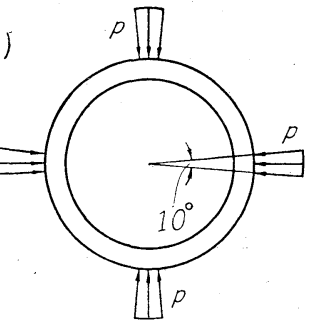

$\sin n \theta]$

$$
\tau_{r \theta}=H_{0} r^{-2}
$$$$
+2\left(A_{1} r-B_{1} r^{-3}+D_{1} r^{-1}\right) \sin \theta
$$$$
-2\left(A_{1}^{\prime} r-B_{1}^{\prime} r^{-3}+D_{1}^{\prime} r^{-1}\right) \cos \theta
$$$$
+\sum_{n=2}^{\infty}\left[n \left\{(n+1) A_{n} r^{n}-(n+1) B_{n} r-n-2\right.\right.
$$$$
\left.+(n-1) C_{n} r^{n-2}-(n-1) D_{n} r^{-n}\right\} \sin n \theta
$$$$
-n\left\{(n+1) A_{n}^{\prime} r^{n}-(n+1) B_{n}^{\prime} r^{-n-2}\right.
$$$$
\left.\left.+(n-1) C_{n}^{\prime} r^{n-2}-(n-1) D_{n}^{\prime} r^{-n}\right\} \cos n \theta\right] \text {. }
$$

境界条件としては， $r=a$ において，

$$
\sigma_{r}=0, \tau_{r \theta}=0 .
$$

また $r=b$ において,

$$
\begin{aligned}
& \sigma_{r}=p_{i} \text { ただし } \theta_{i}-\phi_{i} \leqq \theta \leqq \theta_{i}+\phi_{i}, \\
& \sigma_{r}=0, \text { ただし } \theta_{i}+\phi_{i}<\theta<\theta_{i+1}-\phi_{i+1}, \\
& \tau_{r \theta}=0 . \quad \ldots \ldots \ldots \ldots \ldots \ldots \ldots \ldots \ldots \ldots \ldots \ldots \ldots \ldots \ldots \ldots \ldots \ldots \ldots \ldots \ldots \ldots \ldots \ldots \ldots \ldots \ldots \ldots
\end{aligned}
$$

(4b) 式を Fourier 級数に展開し,

$$
\begin{gathered}
\left(\sigma_{r}\right)_{r=3}=a_{0}+a_{1} \cos \theta+b_{1} \sin \theta \\
+\sum_{n=2}^{\infty}\left(a_{n} \cos n \theta+b_{n} \sin n \theta\right),
\end{gathered}
$$
ここに,

$$
\begin{aligned}
& a_{0}=\frac{1}{2 \pi} \int_{0}^{2 \pi} f(\theta) d \theta, a_{1}=\frac{1}{\pi} \int_{0}^{2 \pi} f(\theta) \cos \theta d \theta, \\
& a_{n}=\frac{1}{\pi} \int_{0}^{2 \pi} f(\theta) \cos n \theta d \theta, \\
& b_{1}=\frac{1}{\pi} \int_{0}^{2 \pi} f(\theta) \sin \theta d \theta,
\end{aligned}
$$

$$
\cos ^{2} \theta \quad(3)-1
$$

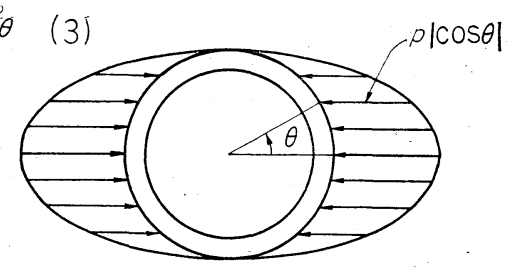

(6)

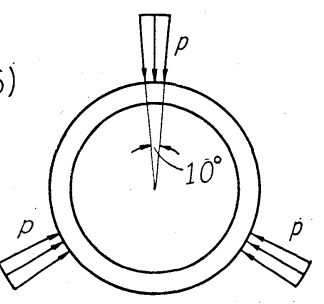

(9)

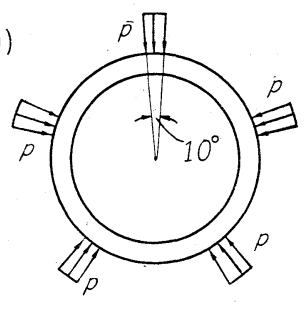

第 2 図 ライニングに作用する9 種類の地圧状態 


$$
b_{n}=\frac{1}{\pi} \int_{0}^{2 \pi} f(\theta) \sin n \theta d \theta .
$$

したがって (4b) 式は次のようになる。

$$
\begin{gathered}
\left(\sigma_{r}\right)_{r=b}=\frac{2}{\pi} \sum_{i=1}^{m} p_{i}\left\{\frac{\phi_{i}}{2}+\sum_{n=2}^{\infty} \frac{1}{n} \sin n \phi_{i}\right. \\
\left(\cos n \theta_{i} \cos n \theta+\sin n \theta_{i} \sin n \theta\right\} \cdots \cdots \cdots(6)
\end{gathered}
$$

これらの境界条件から；(5) 式の定数を決定すればつぎ のようである。

$$
\begin{aligned}
& A_{0}=\frac{1}{2 \pi} \sum_{i=1}^{m} p_{i} \phi_{i}\left(\frac{b}{a}\right)^{2}, \\
& B_{0}=-\frac{1}{\pi} \sum_{i=1}^{m} p_{i} \phi_{i} \frac{b^{2} a^{2}}{b^{2}-a^{2},} \\
& H_{0}=0 \text {, } \\
& A_{1}=B_{1}=C_{1}=D_{1}=A_{1}{ }^{\prime}=B_{1}{ }^{\prime}=C_{1}{ }^{\prime} \\
& =D_{1}{ }^{\prime}=0 \text {, } \\
& A_{n}=\frac{\beta}{\alpha} \frac{1}{n+1} \frac{b^{n}}{a^{2 n}} \\
& \left\{\left(\frac{b}{a}\right)^{2 n}+n\left(\frac{b}{a}\right)^{2}-(n+1)\right\}, \\
& B_{n}=-\frac{\beta}{\alpha} \frac{1}{n+1} b^{n+2} \\
& \left\{(n+1)\left(\frac{b}{a}\right)^{2 n}-n\left(\frac{b}{a}\right)^{2 n-1}-1\right\}, \\
& C_{n}=-\frac{\beta}{\alpha} \frac{1}{n-1} \frac{b^{n}}{a^{2 n-2}} \\
& \left\{\left(-\frac{b}{a}\right)^{2 n+2}+(n-1)\left(\frac{b}{a}\right)^{2}-n\right\}, \\
& D_{n}=\frac{\beta}{\alpha} \frac{1}{n-1} b^{n} \\
& \left\{n\left(\frac{b}{a}\right)^{2 n+2}-(n-1)\left(\frac{b}{a}\right)^{2 n}-1\right\}, \\
& A_{n^{\prime}}=\frac{\gamma}{\alpha} \frac{1}{n+1} \frac{b^{n}}{a^{2 n}} \\
& \left\{\left(\frac{b}{a}\right)^{2 n}+n\left(\frac{b}{a}\right)^{2}-(n+1)\right\}, \\
& B_{n^{\prime}}=-\frac{\gamma}{\alpha} \frac{1}{n+1} b^{n+2} \\
& \left\{(n+1)\left(\frac{b}{a}\right)^{2 n}-n\left(\frac{b}{a}\right)^{2 n-2}-1\right\}, \\
& C_{n}{ }^{\prime}=-\frac{\gamma}{\alpha} \frac{1}{n-1} \frac{b^{n}}{a^{2 n-2}} \\
& \left\{\left(\frac{b}{a}\right)^{2 n+2}+(n-1)\left(\frac{b}{a}\right)^{2}-n\right\}, \\
& D_{n^{\prime}}=\frac{\gamma}{\alpha} \frac{1}{n-1} b^{n} \\
& \left.\left\{n\left(\frac{b}{a}\right)^{2 n+2}-(n-1)\left(\frac{b}{a}\right)^{2 n}-1\right\}\right\}
\end{aligned}
$$

ここに,

$$
\alpha=\left\{\left(\frac{b}{a}\right)^{2 n}-1\right\}^{2}
$$

$$
\begin{gathered}
-\left\{\left(\frac{b}{a}\right)^{2}-1\right\}^{2} n^{2}\left(\frac{b}{a}\right)^{2 n-2}, \\
\beta=\frac{1}{n \pi} \sum_{i=1}^{m} p_{i} \sin n \phi_{i} \cos n \theta_{i}, \\
\gamma=\frac{1}{n \pi} \sum_{i=1}^{m} p_{i} \sin n \phi_{i} \sin n \theta_{i} .
\end{gathered}
$$

(3a)，(3b) および (3c) 式の中の定数に（7) 式を代入 したものが求めようとする $\sigma_{r}, \sigma_{\theta}$ および $\tau_{r \theta}$ の解であ る。しかし，これらの式は長いから，ここに再録するこ とをさけ，とくに内壁および外壁面上の接線方向の応力 を示すと次式のようになる。

$$
\begin{aligned}
& \left(\sigma_{\theta}\right)_{r=a}=\frac{2}{\pi} \sum_{i=1}^{m} p_{i} \phi_{i} \frac{b^{2}}{b^{2}-a^{2}} \\
& -\frac{4}{\pi} \frac{b^{2}-a^{2}}{a^{2}} \sum_{n=2}^{\infty}\left[\frac{1}{\alpha}\left(\frac{b}{a}\right)^{n}\right. \\
& \left\{\left(\frac{b}{a}\right)^{2 n}-1\right\} \sum_{i=1}^{m} p_{i} \sin n \phi_{i} \cos n \\
& \left.\left(\theta_{i}-\theta\right)\right], \\
& \left(\sigma_{\theta}\right)_{r=b}=\frac{1}{\pi} \sum_{i=1}^{m} p_{i} \phi_{i} \frac{b^{2}+a^{2}}{b^{2}-a^{2}} \\
& +\frac{2}{\pi} \sum_{n=2}^{\infty}\left[\frac { 1 } { n \alpha } \left\{\left[\left(\frac{b}{a}\right)^{2 n}-1\right]^{2}\right.\right. \\
& +\left(\frac{b^{2}-a^{2}}{a^{2}}\right)^{2} n^{2}\left(\frac{b}{a}\right)^{2 n-2} \\
& \left.\left.\ldots \sum_{i=1}^{m} p_{i} \sin n \phi_{i} \cos n\left(\theta_{i}-\theta\right)\right\}\right]
\end{aligned}
$$

\section{$2 \cdot 2$ ライニングの外壁面にだ円に似た分布をなす地 圧が作用する場合の応力}

(i) 第2図 (2) に示すように，ライニングに作用す 地压が $p \cos ^{2} \theta$ で表わされる場合は，境界条件を表わ す $(4 \mathrm{~b})$ 式の代りに,

$\sigma_{r}=p \cos ^{2} \theta$

を用いることにより，(3a)，(3b)，(3c）における各定数 は次のように決定できる。

$$
\begin{aligned}
& A_{0}=\frac{p}{4} \frac{b^{2}}{b^{2}-a^{2}}, \\
& B_{0}=-\frac{p}{2} \frac{b^{2} a^{2}}{b^{2}-a^{2}}, \\
& A_{2}=\frac{p}{12} \frac{b^{2}}{\left(b^{2}-a^{2}\right)^{3}}\left(b^{2}+3 a^{2}\right), \\
& B_{2}=-\frac{p}{12} \frac{b^{4} a^{4}}{\left(b^{2}-a^{2}\right)^{3}}\left(3 b^{2}+a^{2}\right), \\
& C_{2}=-\frac{p}{4} \frac{b^{2}}{\left(b^{2}-a^{2}\right)^{3}}\left(b^{4}+b^{2} a^{2}+2 a^{4}\right), \\
& D_{2}=\frac{p}{4} \frac{b^{2} a^{2}}{\left(b^{2}-a^{2}\right)^{3}}\left(2 b^{4}+b^{2} a^{2}+a^{4}\right), \\
& \text { その他の定数=0. }
\end{aligned}
$$

(3a), (3b) および (3c) 式の中の定数䎲（11）式を代入 すると，求めようとする $\sigma_{r}, \sigma \theta$ 抢よび $\tau_{r \theta}$ が下に示す 
ように得られる。

$$
\begin{aligned}
\sigma_{r}= & \frac{p}{2} \frac{b^{2}}{b^{2}-a^{2}}\left[\left(1-a^{2} r^{-2}\right)\right. \\
& +\frac{1}{\left(b^{2}-a^{2}\right)^{2}}\left\{b^{4}+b^{2} a^{2}+2 a^{4}\right. \\
& -2 a^{2}\left(2 b^{4}+b^{2} a^{2}+a^{4}\right) r^{-2} \\
& \left.\left.+b^{2} a^{4}\left(3 b^{2}+a^{2}\right) r^{-4}\right\} \cos 2 \theta\right], \\
\sigma_{\theta}= & \frac{p}{2} \frac{b^{2}}{b^{2}-a^{2}}\left[\left(1+a^{2} r^{-2}\right)\right. \\
& +\frac{1}{\left(b^{2}-a^{2}\right)^{2}}\left\{2\left(b^{2}+3 a^{2}\right) r^{2}\right. \\
& -\left(b^{4}+b^{2} a^{2}+2 a^{4}\right) \\
& \left.\left.-b^{2} a^{4}\left(3 b^{2}+a^{2}\right) r^{-4}\right\} \cos 2 \theta\right], \\
\tau_{r \theta}= & \frac{p}{2} \frac{b^{2}}{\left(b^{2}-a^{2}\right)^{3}}\left\{\left(b^{2}+3 a^{2}\right) r^{2}\right. \\
& -\left(b^{4}+b^{2} a^{2}+2 a^{4}\right) \\
& -a^{2}\left(2 b^{4}+b^{2} a^{2}+a^{4}\right) r^{-2} \\
& \left.+b^{2} a^{4}\left(3 b^{2}+a^{2}\right) r^{-4}\right\}(\sin 2 \theta) .
\end{aligned}
$$

とくに, 内壁および外壁面上の接線方向の応力は次のよ らである。

$$
\begin{gathered}
\left(\sigma_{\theta}\right)_{r=a}=p\left\{\frac{b^{2}}{b^{2}-a^{2}}\right. \\
\left.-\frac{2 b^{2}\left(b^{2}+a^{2}\right)}{\left(b^{2}-a^{2}\right)^{2}} \cos 2 \theta\right\}, \\
\left(\sigma_{\theta}\right)_{r=b}=\frac{p}{2}\left\{\frac{b^{2}+a^{2}}{b^{2}-a^{2}}\right. \\
\left.+\frac{b^{4}+6 b^{2} a^{2}+a^{4}}{\left(b^{2}-a^{2}\right)^{2}} \cos 2 \theta\right\}
\end{gathered}
$$

(ii) 第 2 図(3) に示すように, ライニングに作用する 地圧が $p|\cos \theta|$ で表わされる場合は，境界条件を表わ す (4b) 式および (4c) 式の代りに,

$$
\sigma_{r}=p \cos ^{2} \theta, \quad \tau_{r \theta}=p \cos \theta \sin \theta
$$

を用いることにより，(3a)，(3b) および (3c) 式の中 の各定数は次の上うに決定できる。

$$
\begin{aligned}
& A_{0}=\frac{p}{4} \frac{b^{2}}{b^{2}-a^{2}}, \\
& B_{0}=-\frac{p}{2} \frac{b^{2} a^{2}}{b^{2}-a^{2}}, \\
& A_{2}=\frac{p}{6} \frac{b^{4}}{\left(b^{2}-a^{2}\right)^{3}}, \\
& B_{2}=-\frac{p}{12} \frac{b^{4} a^{4}}{\left(b^{2}-a^{2}\right)^{3}}\left(3 b^{2}-a^{2}\right), \\
& C_{2}=-\frac{p}{4} \frac{b^{4}}{\left(b^{2}-a^{2}\right)^{3}}\left(b^{2}+a^{2}\right), \\
& D_{2}=-\frac{p}{2} \frac{b^{6} a^{2}}{\left(b^{2}-a^{2}\right)^{3}}, \\
& \text { その他の定数=0. }
\end{aligned}
$$

これらの式を (3a), (3b) および (3c) 式の中の定数に
代入すると求めようとする $\sigma_{r}, \sigma_{\theta}$ および $r \theta$ が得られ る。とくに, 内壁および外壁面上での接線方向の応力は 次式で与えられる。

$$
\begin{gathered}
\left(\sigma_{\theta}\right)_{r=a}=p\left\{\frac{b^{2}}{b^{2}-a^{2}}\right. \\
\left.-\frac{2 b^{4}}{\left(b^{2}-a^{2}\right)^{2}} \cos 2 \theta\right\}, \\
\left(\sigma_{\theta}\right)_{r=b}=\frac{p}{2}\left\{\frac{b^{2}+a^{2}}{b^{2}-a^{2}}\right. \\
\left.+\frac{\left(b^{2}+a^{2}\right)\left(3 b^{2}-a^{2}\right)}{a^{2}\left(b^{2}-a^{2}\right)} \cos 2 \theta\right\} .
\end{gathered}
$$

(iii) 第 2 図 (1) に示すように，ライニングに均等地圧 が作用する場合は，境界条件を示す (4b) 式の代りに,

$$
\sigma_{r}=p
$$

を用いることにより,各定数はつぎのように決定できる。

$$
\begin{aligned}
& A_{0}=\frac{1}{2} \frac{b^{2}}{b^{2}-a^{2}} p, \quad B_{0}=-\frac{b^{2} a^{2}}{b^{2}-a^{2}} p, \\
& \text { その他の定数=0. }
\end{aligned}
$$

(17) 式を（3a)，(3b)，(3c) 式に代入し

$$
\left.\begin{array}{l}
\sigma_{r}=\frac{b^{2}}{b^{2}-a^{2}}\left(1-a^{2} r^{-2}\right) p \\
\sigma_{\theta}=\frac{b^{2}}{b^{2}-a^{2}}\left(1-a^{2} r^{-2}\right) p \\
\tau_{r \theta}=0
\end{array}\right\}
$$

とくに，内壁および外壁面上での接線方向の忘力は，

$$
\left.\begin{array}{c}
\left(\sigma_{\theta}\right)_{r=a}=\frac{2 b^{2}}{b^{2}-a^{2}} p \\
\left(\sigma_{\theta}\right)_{r=\boldsymbol{b}}=\frac{b^{2}+a^{2}}{b^{2}-a^{2}} p
\end{array}\right\}
$$

\section{3. 数值計算によるライニング内 の応力に関する検討}

ライニングの水平断面上では，壁面上の接線方向の応 力の極大值はライニング内の応力の極大值であるから， 壁面上の接線比向の応力を知ることは有意義である。そ こで, 種々の地王状態の場合について, 種々のライニン グの厚さに対して，この応力を計算することにする。

まず，地圧状態が変化すれば，ライニング内の応力が いかに変化するかを知るために， $b / a=1.25$ とし，第 2 図に示す 3 種類の分布地压と 6 種類の集中地圧の場合に ついて，総地庄は同一として，内外壁面上の接線方向の 応力を計算した結果は第 3 困のようである。この図の中 の各図面の左肩に示した小さな図は地圧状態の説明図で ある。壁面上の接線方向の応力は，壁面上の各点から法 線を立て，その上に下方に示したスケールによつてとつ て示されており，引張応力は中心に向ら法線上に，压縮 応力は外側に向ら法線上にとられている。どの場合も応 力の大きさは平均地压 $\bar{p}$ の倍数として示されていて，各 種の地圧状態の下の応力の比較を容易にしている。ここ 
(1)

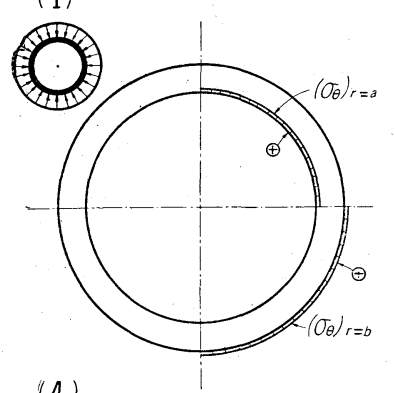

(4)

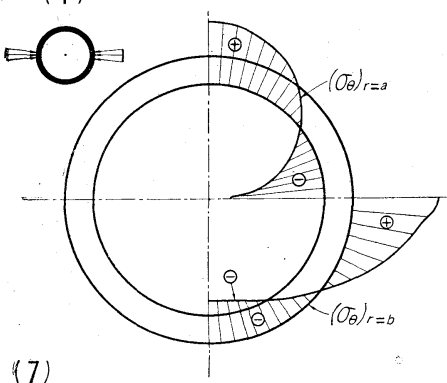

(7)

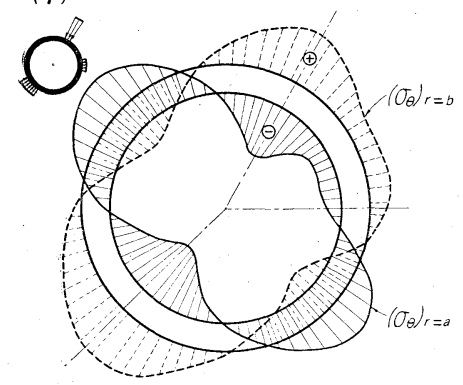

(2)

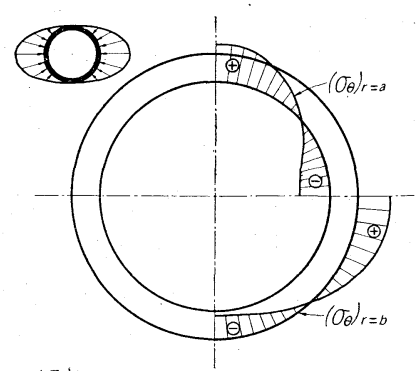

(5)

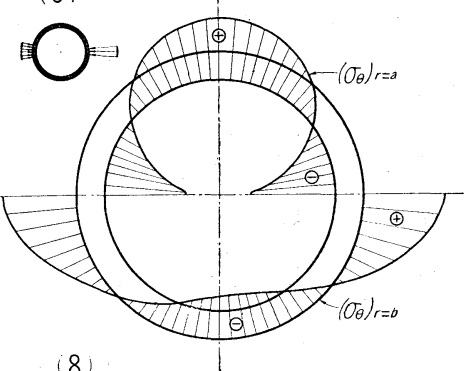

(8)

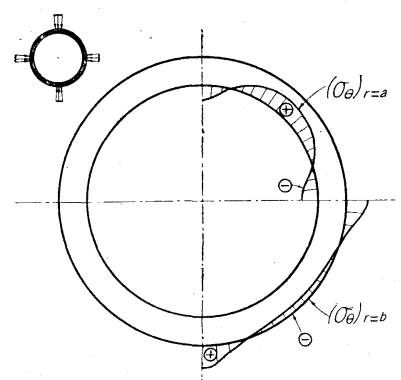

(3)

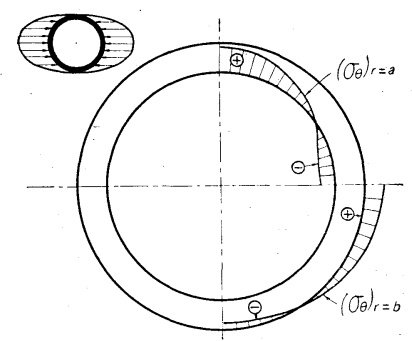

(6)

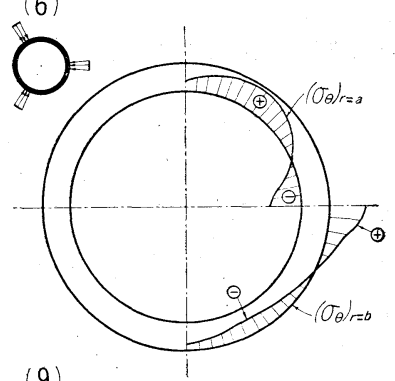

(9)

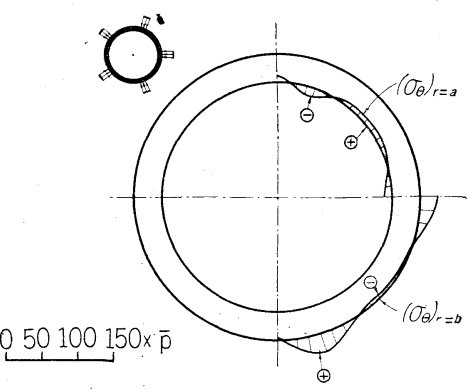

$(\oplus は$ 縮応力, $\ominus$ は引張応力を示す)

第3圈 9 種類の地圧の下に; ライニングの内外壁面上に生ずる王力の分布

に平均地圧市としては, ライニングの外壁面に垂直に作 用する地圧を全外壁面にわたつて積分した值を外壁面の 面積で除した值をとつており，次式で与えられる。

集中地圧の埸合, $\bar{p}=\frac{1}{2 \pi} \int_{0}^{2 \pi} p d \theta$, (19a)

均等地圧の場合, $\bar{p}=p_{0}, \cdots$

だ円に似た分布地圧の場命，

$$
\bar{p}=\frac{1}{2 \pi} \int_{0}^{2 \pi} p \cos ^{2} \theta d \theta=\frac{1}{2} p .
$$

第 2 図 (2) および (3) に示されているように，地圧が だ円に似た分布をなす場合には，水平断面上の最大引張 応力 $\sigma_{T}$ は内壁面上の $\theta=0$ 预よび $\theta=\pi$ の点记生じ, 最大圧縮応力 $\sigma o$ は内壁面上の $\theta=\frac{\pi}{2}$ およ゙ $\theta=\frac{3}{2} \pi$ の 点に特じる。また，第 2 図 (4), (5), (6), (8) および (9) に示されているような地玨状態の場合には， $\sigma_{T}$ はそれ ぞれ各分布地圧の中心を通る半径と内壁面との交点に坐

* фが非常飞小さくなつても, 壁面上の接線方向最大応力は, 第 4

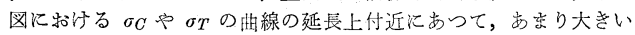
值とはならないが，このような場合汇限り，地圧が作用なる点の半 径方向の応力が最大となる。
じ， $\sigma_{\sigma}$ はこれらの半径の端の点，すなわち分布荷重が 作用する籁囲の中心に生じる。均等地圧の場合には, 内 壁面上に一様な最大圧縮店力 $\sigma_{0}$ が生じる。

第 3 図から、ライニングに不均等地圧が作用する場合 は，その平均值と同じ強さの均等地圧が作用する場合に 比べて，はるかに高い厓縮応力と，それと同程度の引張 忘力とが韭ずることが分る。

Mohr 教授注第 3 図 (2) の場合の応力を構造力学的方 法によって近似的に解析している ${ }^{3)}$ 。乙の結果から壁面 上の応力を計算した值は, 弾性理論によつて解析したわ れわれの結果から計算した值よりいくぶん小さい。

つぎに，集中的地圧の分布する幅がライニングの虑力 に及ぼす影響を知るために，1つの直径にそつて，2方 向からライニングに集中的地压が作用する場合につい て総地压は一定として, $\phi=2^{\circ} \sim 15^{\circ}$ の範围内で $\phi$ 己 $\sigma r$ および $\sigma_{C}$ との関係を示せば第 4 図のようである。この 計算結果から，集中的地圧の分布する幅が増すととも に, 最大応力はいくぶん低下するが, その影響はさほど 大きくないことが分る*。 


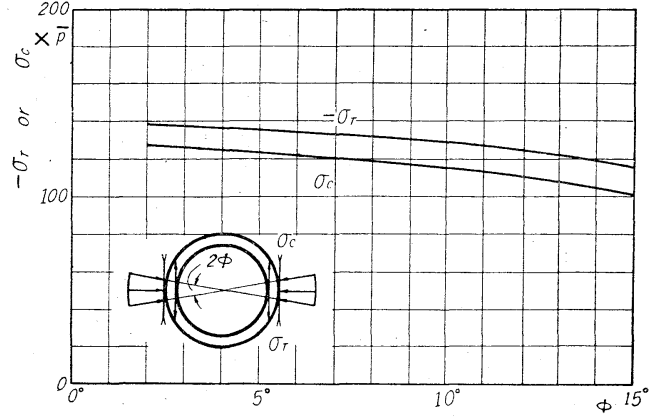

第4 図・ $\phi$ と $\sigma_{T}$ および $\sigma_{C}$ との関係，ただし $b / a=1.25$

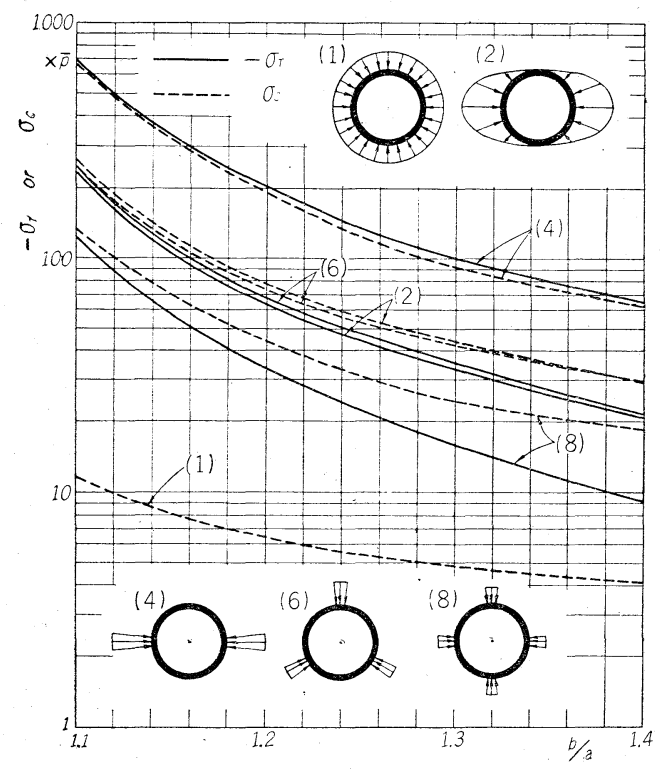

第5図 $b / a$ と $\sigma_{T}$ 抢よび $\sigma_{C}$ との関係

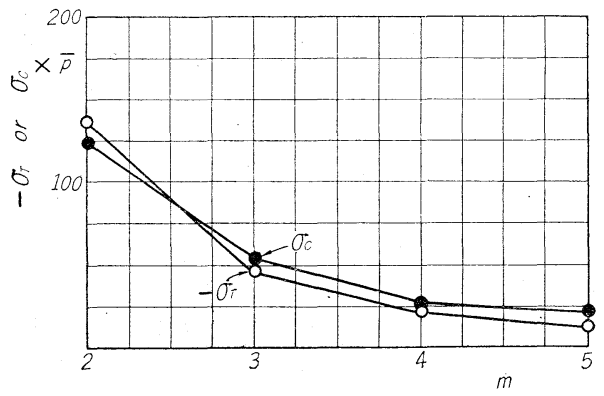

第6 図 等間隔に同一の幅をもつて作用する集 中的地圧の数 $m$ と $\sigma_{T}$ 抢よび $\sigma_{O}$ との関係

またライニングの厚さが応力に及ぼす影響をしらべる ため，均等地圧，だ円に似た分布をなす地圧および 3 種 類の集中地压の 5 つの地圧状態を選んで, そのおのおの について, b/a と $\sigma w$ および $\sigma_{C}$ との関係を示すと第 5 図のようである。この結果から， b/a が小さくなるにつ れて, 寸なわち, ライニングが薄くなるにつれて, 壁面
上の最大引張応力や最大压縮応力が急激に増加すること が分る。

外壁面上の等間隔をなす数個所に，同じ幅を持つ同じ 強さの集中的地压が作用するとき, 地圧の数 $m$ と $\sigma_{T} や$ $\sigma_{C}$ との関係を示せ㳊第 6 図のようである。この図から， ライニングに作用する総地压が一定であれば，2方向か ら集中的に地压が作用する場合，ライニングに最も高い 応力が現われ，集中地圧の数 $m$ が増すとともに，最大応 力は減少することが分る。さらに，第 5 図を参照するこ とにより， $m=2$ の場合の $\sigma_{O}$ は第 2 図 (2) に示すよう なだ円的分布をする地压の場合の $\sigma_{O}$ の約 2.5 倍, 均等地 圧の場合の $\sigma_{C}$ の 15 16 倍である。(b/a の值によつて このような広、範囲がある。)また， $m=2$ の場合の $\sigma_{T}$ は 上と同じだ円的分布の地压の場合の $\sigma_{T}$ の約 3 倍である。 均等地圧と不均等地层とが同時に作用する場合の応力: は，重畳の法則により，おのおのの地圧が別々に作用す る場合の応力を代数的に加えることによつて得られるこ とはいうまでもない。

\section{4. 本研究結果のライニング設計 に対する応用}

以上の解析結果を考慮し，円形立坑ライニングを諾計 する際考慮すべき最大忘力の見積り方について私案を述 べたい。この見積りの前提として, 種々の条件の岩盤中 に開さくされた立坑ライニングに作用する地王が測定さ れていて, 均等地压 $p_{0}$ と不均等地压の平均值 $\bar{p}$ との見 積りが可能であることが必要である。（この点について は，まだ十分な資料はないが，今後も調査を続け，資料 を豊富にすることに努めたいと思う)。

さて，ライニング内に最も高い忘力集中を起させる不 均等地压は, 総地压が同一であれば，2方向から集中的 に作用する場合であるから，総不等地圧が，1つの直径 に沿つて 2 方向から集中的に作用するものとして計算し た $\sigma_{T}$ や $\sigma O$ は最も安全側の見積りである。また不均等 地压がだ円に似た分布をなすと仮定して $\sigma_{T}$ や $\sigma \sigma$ を計 算すれば，かなり低い值が得られる。そこでこれらの 2 つの方法で計算した $\sigma_{T}$ や $\sigma_{O}$ の值を見積りの上限と下 限とし，地盤の状態を考慮して，これらの值の中間に適 当に見積るのが妥当であろらと思われる。

$\sigma_{T}$ や $\sigma_{C}$ の 2 つの限界值を迅速に計算するのに用い る式として，(9)，(12）および (18)式を考慮して，(20)， (21) 式を提案する。

$\sigma_{T}, \sigma_{C}$ の值の上限 :

$$
\left.\begin{array}{l}
\sigma_{T} \fallingdotseq \frac{2 b^{2}}{b^{2}-a^{2}} p_{0}-3\left\{\frac{2 b^{2}\left(b^{2}+3 a^{2}\right)}{\left(b^{2}-a^{2}\right)^{2}}\right\} \bar{p}, \\
\sigma_{O} \fallingdotseq \frac{b^{2}+a^{2}}{b^{2}-a^{2}} p_{0}+2.5\left\{\frac{2 b^{2}\left(3 b^{2}+a^{2}\right)}{\left(b^{2}-a^{2}\right)^{2}}\right\} \bar{p} .
\end{array}\right\}
$$

$\sigma_{T}, \sigma_{C}$ の值の下限： 


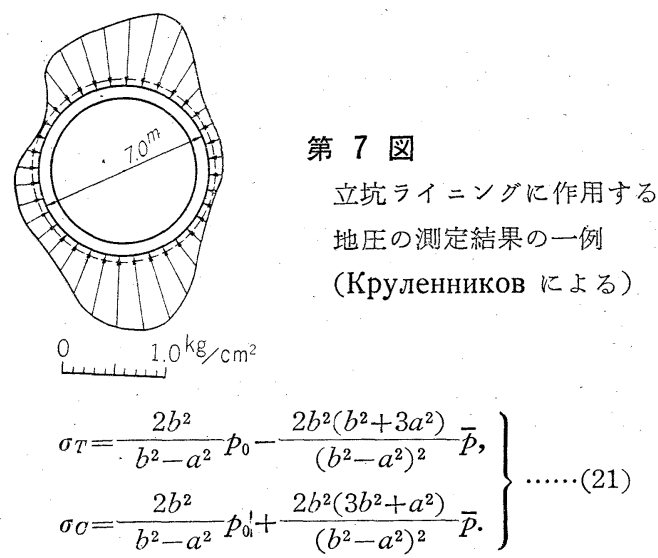

例 1. ライニングに第 7 図に示すような地圧**が作用す る場合, この図から

均等地压 $p_{0}=0.08 \mathrm{~kg} / \mathrm{cm}^{2}$,

不均等地圧の合計 $=79,600 \mathrm{~kg} / \mathrm{cm}$,

不均等地压の平均值 $\bar{p}=0.36 \mathrm{~kg} / \mathrm{cm}^{2}$

と計算される。このような地盤中に開さくされる立坑う イニングを設計する资料として，上に述べた方法で最大 応力を見積ると次のようである。

第1表 ライニング設計のために $\sigma_{T}$ 抢よび $\sigma_{O}$ を見積つた值 (例 1 ) (単位は $\mathrm{kg} / \mathrm{cm}^{2}$ )

\begin{tabular}{|c|c|c|c|c|c|c|}
\hline \multirow{2}{*}{$\frac{b / a}{\text { 最大応力 }}$} & \multicolumn{2}{|c|}{ 1. 1} & \multicolumn{2}{|c|}{ 1. 2} & \multicolumn{2}{|c|}{ 1. 3} \\
\hline & $\sigma_{T}$ & $\sigma_{C}$ & $\sigma_{T}$ & $\sigma_{C}$ & $\sigma_{T}$ & $\sigma_{C}$ \\
\hline 卡 & $\begin{array}{r}-250 \\
-83\end{array}$ & $\begin{array}{r}250 \\
93\end{array}$ & $\begin{array}{l}-84 \\
-28\end{array}$ & $\begin{array}{l}84 \\
34\end{array}$ & $\begin{array}{l}-30 \\
-10\end{array}$ & $\begin{array}{l}34 \\
14\end{array}$ \\
\hline
\end{tabular}

例 2. 四紀層中に開さくされる立玩のように，比較的均 等な地圧が作用する場合の例として， $p_{0}=10 \mathrm{~kg} / \mathrm{cm}^{2}$, $\bar{p} / p_{0}=0.05$ と見積られるとき, 例 1 と同様の計算によ り, ライニング中の最大応力を見積ると第 2 表のようで ある。

第2表 ライニングの設計のために $\sigma_{T}$ 拈よび $\sigma_{O}$ を見積つた值 (例 2 ) (単位は $\mathrm{kg} / \mathrm{cm}^{2}$ )

\begin{tabular}{|c|c|c|c|c|c|c|c|}
\hline \multirow{2}{*}{\multicolumn{2}{|c|}{$\frac{b / a}{\text { 最大応力 }}$}} & \multicolumn{2}{|c|}{1.1} & \multicolumn{2}{|c|}{ 1. 2} & \multicolumn{2}{|c|}{ 1. 3} \\
\hline & & $\sigma_{T}$ & $\sigma_{C}$ & $\sigma_{T}$ & $\sigma_{C}$ & $\sigma_{T}$ & $\sigma_{C}$ \\
\hline 卡 & 限 & $\begin{array}{l}-226 \\
-0.3\end{array}$ & $\begin{array}{l}432 \\
242\end{array}$ & -51 & $\begin{array}{l}160 \\
112\end{array}$ & -8 & $\begin{array}{l}90 \\
59\end{array}$ \\
\hline
\end{tabular}

* 交献 1) 飞挙げた Круленников の論文中に記載されている ルガンスカヤ No. 1 崖鉱ケージ卷立坑の実測例で, この立坑タビ ングは破壊した由である。

\section{5. 結 論}

立坑ライニングに均等地王, 種々の条件の不均等地压 あるマはその両者が同時に作用する場合, ライニングに 現われる応力を弾性理論によつて解析し, 種々の地压状 態の下におけるライニングの応力を明らかにした。その 一般的傾向を示せば次のようである。

（1）ライニングに不均等地圧が作用する場合は，均 等な地压が作用する場合に比べて，はるかに高い王縮応 力と, それと同程度の引張応力とが生じる。

（2）集中的地圧が作用する場合，その分布する幅は ライニング内の応力に余り大きい影響を及ぼさない。

(3) ライニングが薄くなるにつれて最大引張応力と 最大圧縮応力は急激に増加する。

（4）ライニングに作用する総地圧が一定であれば, 2 方向から集中的に地圧が作用寸る場合, ライニングに 最も高、圧縮応力やそれと同程度の引張応力が現われ， 最大王縮応力は均等地压の場合のそれの15～60倍に達す る。集中地圧の数が増すと共に応力は減少する。だ円に 似た分布をなす地压が作用守る場合 [第 2 図(2)]，ライ ニング内の最大応力は 2 方向から集中的作用する場合 の $1 / 2.5 \sim 1 / 3$ である。

（5）ライニングに均等地庄と不均等地压とが同時に 作用する場合, 不均等地压がある限度以上に達するとラ イニング内に引張怘力を垚じるようになる。

最後に, ライニングを設計するに当つて，最大応力を 見積る方法の 1 案を提案した。

\section{参考文 献}

1) B. Bals: Glückauf 85. Jg., H.21/22, 21. Mai 1949, S. 367 380 .

F. Mohr : Gluickauf 86. Jg., H. 23/24, 10, Juni 1950, S. 437 $\sim 452$.

F. W ansleben : Glückauf 89. Jg, H. 49/50, Dez. 1953, S. 1129 $\sim 1132$.

Г. А. Крупенников : ウーゴу 17, 1959, 48〜52頁,

R. Shepherd, A. H. Wilson: Coll. Guard. Vol. 200, No. 5161, March 17, 1960, p. 235 291.

2）平松・岡: 日本釷業会誌，76巻，868号，昭和35年 8 月，543～548 頁

5) F. Mohr：支献 1) に挙げた論交中のMohr の論文 